\title{
Armatambo y la sociedad Ychsma
}

Armatambo et la société Ychsma

Armatambo and the Ychsma Society

Luisa E. Díaz Arriola

\section{CpenEdition}

\section{Journals}

Edición electrónica

URL: http://journals.openedition.org/bifea/5136

DOI: $10.4000 /$ bifea. 5136

ISSN: 2076-5827

Editor

Institut Français d'Études Andines

Edición impresa

Fecha de publicación: 1 diciembre 2004

Paginación: 571-594

ISSN: 0303-7495

Referencia electrónica

Luisa E. Díaz Arriola, "Armatambo y la sociedad Ychsma », Bulletin de l'Institut français d'études andines [En línea], 33 (3) | 2004, Publicado el 08 diciembre 2004, consultado el 01 diciembre 2020. URL : http:// journals.openedition.org/bifea/5136; DOI : https://doi.org/10.4000/bifea.5136

\section{(c) (i) $\odot$}

Les contenus du Bulletin de l'Institut français d'études andines sont mis à disposition selon les termes de la licence Creative Commons Attribution - Pas d'Utilisation Commerciale - Pas de Modification 4.0 International. 
Bull. Inst. fr. études andines

2004, 33 (3): 571-594

\title{
ARMATAMBO Y LA SOCIEDAD YCHSMA
}

\author{
Luisa E. DÍAZ ARRIOLA *
}

\section{Resumen}

El presente documento busca caracterizar de manera preliminar la ocupación cultural Ychsma de Armatambo (al sur de Lima, Perú), correspondiente a los periodos Intermedio Tardío e Inca. Para ello, partimos de nuestras investigaciones llevadas a cabo en ese sitio entre los años 1998 y 2004. Como primer paso nos hemos planteado la necesidad de disgregar las evidencias arqueológicas Ychsma, de carácter local, de las manifestaciones culturales Inca. Esto nos permitirá iniciar la construcción de una secuencia cultural sólida de Armatambo, para llegar a conocer el proceso de formación social y ocupación Ychsma en esta parte de Lima.

Palabras claves: Armatambo, periodo Intermedio Tardío, periodo Inca, arquitectura Ychsma, patrón funerario Ychsma, mullu.

\section{Résumé}

\section{ARMATAMBO ET LA SOCIÉTÉ YCHSMA}

Le présent essai a pour objectif de caractériser de manière préliminaire l'occupation culturelle Ychsma de Armatambo (au sud de Lima, Pérou), laquelle correspond aux périodes Intermédiaire récent et Inca. Pour se faire, nous nous basons sur les recherches conduites sur le site entre 1998 et 2004. Dans un premier temps, il nous apparaît nécessaire de différencier les éléments archéologiques Ychsma, de caractère local, des manifestations culturelles incas. Cette première étape permettra d'élaborer une séquence culturelle de référence pour Armatambo et, partant, de définir le processus d'occupation et de développement social Ychsma dans cette partie de la vallée.

Mots clés :Armatambo, période Intermédiaire récent, période inca, architecture Ychsma, modèle funéraire Ychsma, mullu.

\footnotetext{
*Directora. Proyecto Arqueológico Armatambo. E-mail: ledarriola@yahoo.es
} 


\title{
ARMATAMBO AND THE YCHSMA SOCIETY
}

\begin{abstract}
This document tries to describe in a provisional way the Ychsma cultural occupation of Armatambo archaeological site (south of Lima, Peru), during the Late Intermediate and Inca Periods. We start from our own investigations in the same site, that were carried out from 1998 until 2004. As a first step, we defined the necessity to separate the archeological discoveries with a local Ychsma character from the finds that express the Inca culture. This will permit us to start and build up a solid cultural secuence for Armatambo, in order to begin to understand the process of social structuring and Ychsma occupation in this part of Lima.
\end{abstract}

Key Words: Armatambo, Intermediate Late Period, Inca Period, Ychsma Architecture, Ychsma Funeral Pattern, Mullu.

\section{UBICACIÓN GEOGRÁFICA Y MEDIO AMBIENTE}

La antigua ciudad de Armatambo se encuentra ubicada en la margen izquierda del cono deyectivo del río Rimac. Se asienta en la ladera oriental del promontorio denominado Morro Solar, el mismo que se encuentra en el distrito de Chorrillos, al sur de la ciudad de Lima (Fig. 1). Este macizo rocoso se caracteriza por ubicarse inmediatamente al pie del mar, y dar continuidad a la geomorfología de la bahía de Chorrillos, la que se inicia en La Punta y culmina al pie de este macizo. La geomorfología del Morro Solar es rocosa y accidentada, dando origen a las playas de La Herradura y La Chira, y en su punto más alto alcanza una altura de 281 m.s.n.m. con una extensión aproximada de 7,48 $\mathrm{km}^{2}$, que corre de Norte a Sur, paralelo al litoral.

La ladera oriental del Morro Solar presenta, en su parte baja, una inclinación que va de suave a moderada, caracterizada por la presencia de suelos formados en la Era Terciaria y cubiertos por depósitos no consolidados del Cuaternario (Fernandez, 1958: 17). Estos suelos son de tres tipos: de origen aluvial, como los observados en las terrazas del Salto del Fraile y La Herradura. Son producto de factores eólicos las playas arenosas de Villa y Conchán, y los de origen fluvial, que son de elementos pocos disgregados que forman parte del abanico aluvial del río Rimac.

Inmediatamente al sur como al este del Morro Solar, anteriormente se podían apreciar bosques y humedales (Fig. 2), ricos en fauna silvestre propia de estos ecosistemas. Hoy solo perduran los humedales de "Pantanos de Villa" por tratarse de una zona ecológica protegida por las leyes peruanas. En esta parte de Lima se pueden identificar cuatro grandes grupos de zonas de vida: biocenosis marinas cercanas a la tierra; de transición entre el mar y la tierra; terrestres cercanas al mar y antropocenosis, las que reunidas configuraron un territorio muy rico para establecer un asentamiento complejo como lo fue Armatambo; demás está decir de su ubicación estratégica en esta parte del litoral de Lima. Armatambo se asentó protegido de las brisas y nubosidades provenientes del mar, aprovechando la topografía inclinada del terreno que le permitió ser un asentamiento orientado hacia las zonas agrícolas (al este), visualmente ligado a 


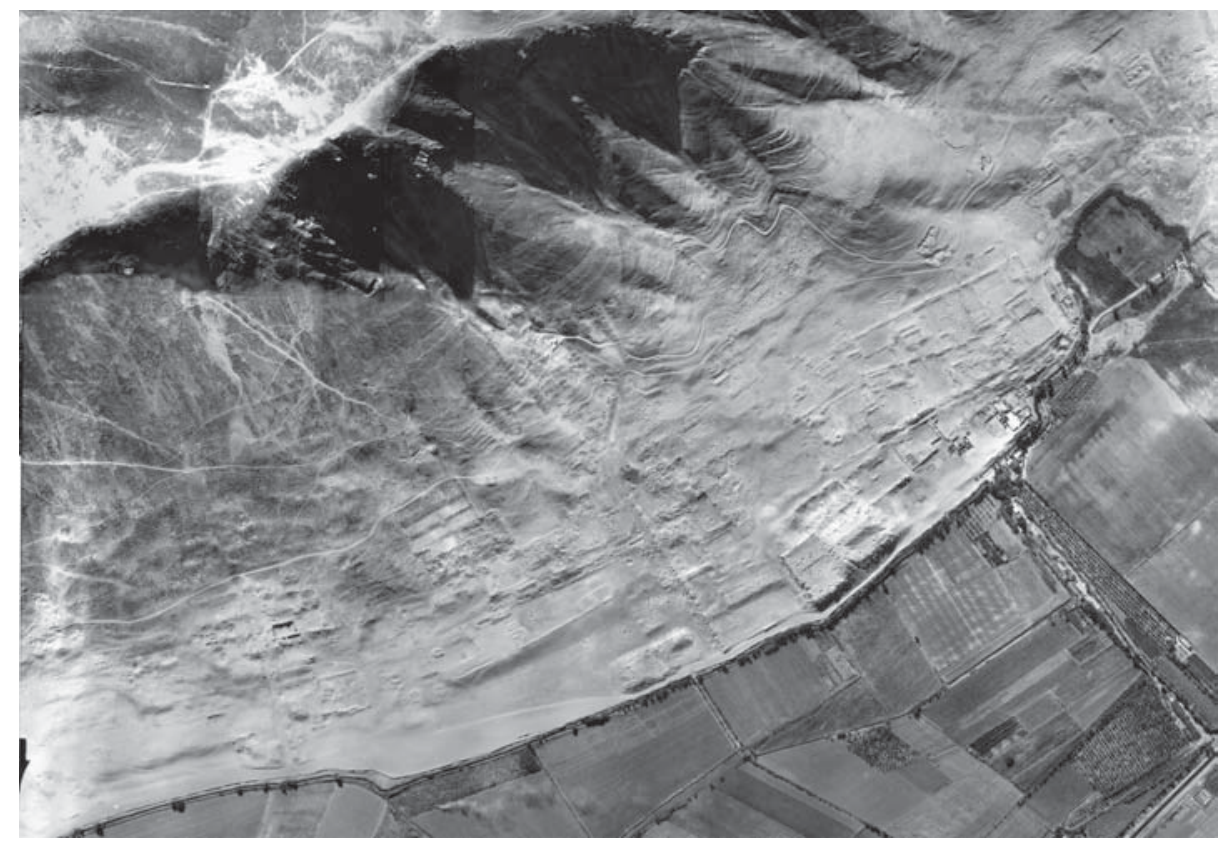

Fig. 1 - Foto aérea de Armatambo, SAN 1945.

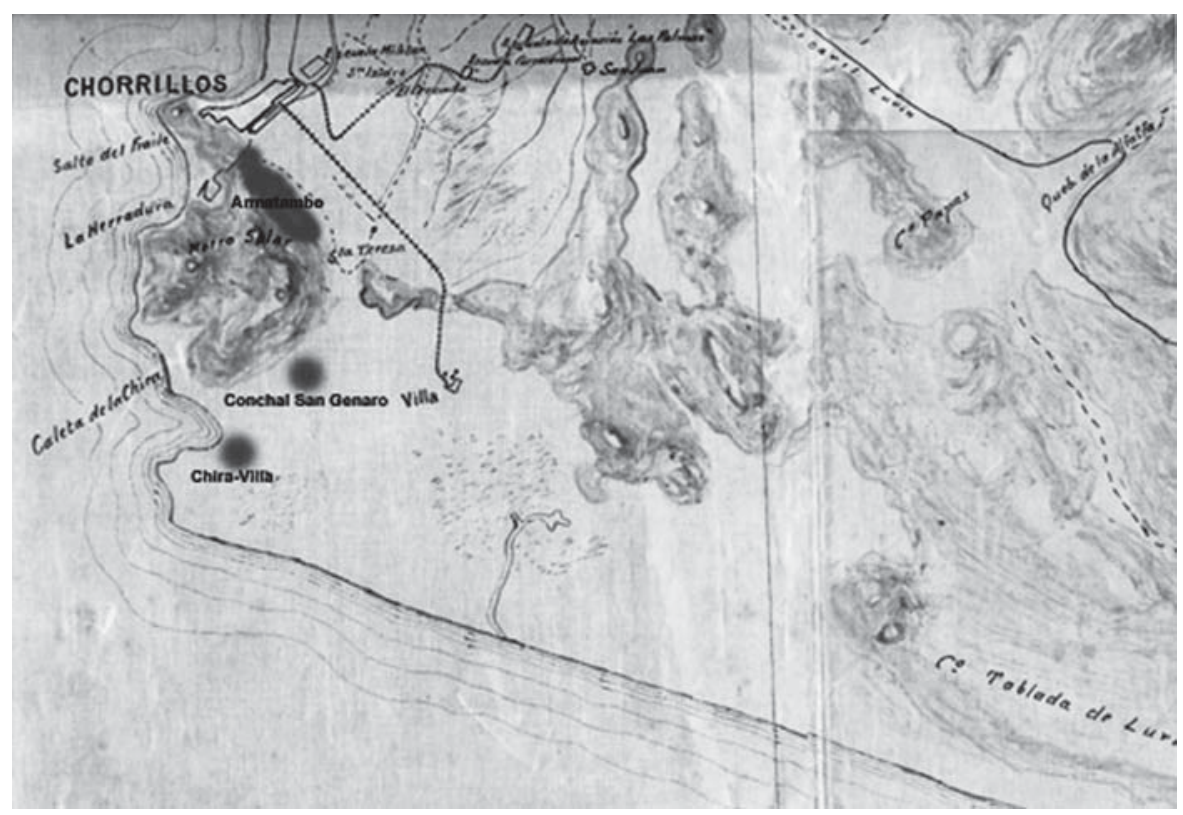

Fig. 2 - Plano de ubicación del Morro Solar y ecosistemas cercanos, tomado de la Sociedad Geográfica de Lima, 1925. 
la ciudad de Pachacamac (Fig. 3) y a inmediaciones de una caleta de pescadores, caracterizada por sus aguas apacibles y de fácil desembarco, que fue muy utilizada por los naturales (Cobo, 1882[1639]; Rostworowski, 1977: 220), lo que hizo de Armatambo el natural puerto de Pachacamac.

\section{ESTADO ACTUAL DE ARMATAMBO}

En la actualidad, el avanzado proceso de consolidación urbano acaecido en las laderas del Morro Solar ha modificado de gran manera las estructuras arqueológicas visibles en Armatambo. Así muchas estructuras han cedido su ubicación a las casas de los actuales moradores, quedando algunas de ellas totalmente sepultadas, mientras que de otras permanecen únicamente las bases estructurales. De otro lado, han sobrevivido de pie únicamente los complejos o edificios arquitectónicos de mayor volumen, que identificamos como huacas aisladas dentro de la nueva trama urbana que se le superpone (Bueno, 1978). Uno de estos espacios es la Huaca San Pedro y sus alrededores, que ha sido motivo de nuestras últimas investigaciones desde enero de 2003 hasta marzo de 2004, donde la evidencia arqueológica recuperada nos ha permitido definir de mejor manera los patrones arquitectónicos, las prácticas mortuorias y las características y cronología de la cerámica Ychsma. Los otros monumentos aún visibles corresponden a la Huaca Los Laureles, Marcavilca, Cruz de Armatambo, Ministerio de Salud y Virgen del Morro.

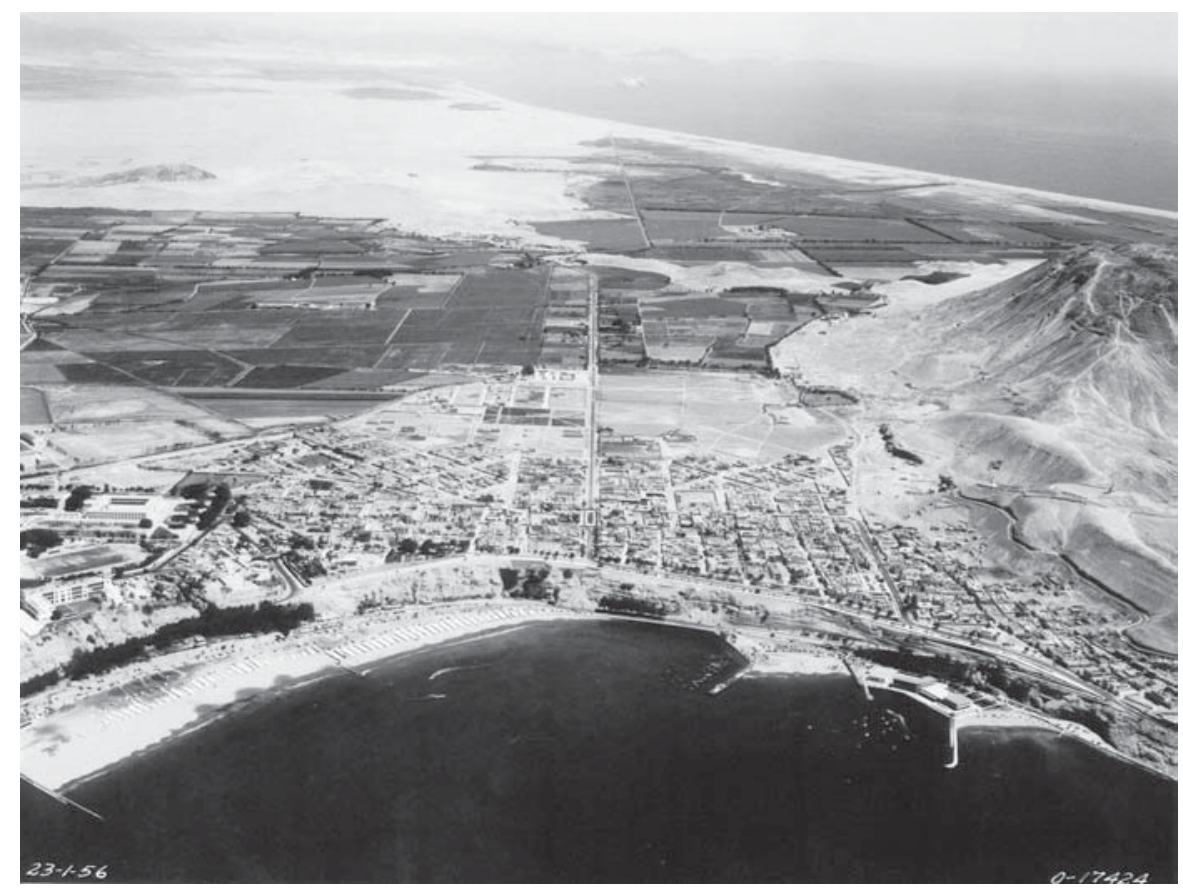

Fig. 3 - Foto aérea oblicua del Morro Solar. Servicio Aéreo Nacional del Perú, 1956. 


\section{LA CIUDAD DE ARMATAMBO}

Armatambo, hoy identificada como la "Zona Arqueológica e Histórica Armatambo-Morro Solar", hacia el siglo XV de nuestra era, fue la sede principal del curacazgo de Sulco o Surco (Bandelier, 1970; Hyslop \& Mujica, 1992 ) que, bajo la supremacía de la antigua ciudad-santuario de Pachacamac, se constituyó en uno de los más importantes centros urbanos de la cultura Ychsma (Rostworowski, 1978: 56). Cultura que administró las cuencas bajas de los ríos Rímac y Lurín, así como el litoral próximo, donde se ubican las islas San Lorenzo y Pachacamac. El curacazgo de Sulco o Surco, comprendía lo que hoy son los distritos de Chorrillos, Barranco, Surco, Surquillo y parte de Miraflores (Rostworowski, 1978: 57; Varón, 1997: 443); era regado por las aguas del canal o "río Surco", cuya toma se iniciaba en el fundo Salinas y terminaba en la hacienda Villa (Cerdán y Pontero, 1901[1793]), siendo además el más importante del valle bajo del Rímac (Díaz \& Vallejo, 2003b: 358). De otro lado, una referencia de la importancia de Armatambo la realiza Cobo (1882[1639] ), quien describe a Armatambo como un lugar con mucha población, donde las casas de los caciques poseían paredes pintadas, y contaba con una huaca y edificaciones bien conservadas. Además menciona que como zona de residencia de sus gobernantes poseía una población que vivía en sus alrededores.

Durante los años trabajados por nosotros en este importante sitio arqueológico, hemos podido observar que la construcción de esta ciudad durante el periodo Ychsma, se realizó modificando la topografía en declive del suelo, lo que se consiguió mediante la preparación de terrazas al nivelar y remover grandes volúmenes y extensiones de terreno. Posteriormente, sobre estos espacios, se erigieron grandes edificaciones, que permanentemente fueron motivo de remodelaciones y transformaciones arquitectónicas, realzando la monumentalidad de Armatambo, acorde con su importancia desde su fundación Ychsma hasta el apogeo incaico.

La ciudad se emplazaba en un eje aproximado de Norte a Sur, y estaba organizada en sectores o "barrios", los que se pueden definir como conjuntos arquitectónicos diferenciados, que se articulaban entre sí mediante un camino principal (eje Norte-Sur), caminos secundarios y pasajes. Al parecer, estos conjuntos habrían tenido funciones de carácter residencial, administrativo y religioso que, en la actualidad, no podemos precisar por la desaparición casi total de los vestigios arqueológicos. Dentro de estos sectores, a modo de reutilizaciones del período Inca, hemos podido verificar la existencia de zonas de cementerio.

En Armatambo sobresale la presencia de algunas pirámides con rampa (de ahora en adelante: PCR) de tamaño variable, las que mayormente se concentraban hacia el lado norte de la ciudad, presentando un eje de orientación general Este-Oeste. Hoy en día las únicas estructuras de este tipo que todavía subsisten son Marcavilca y la PCR (SP1-Ar) de la Huaca San Pedro (Díaz \& Vallejo, 2003a: 51 - 54).

\section{LA ARQUITECTURA EN ARMATAMBO}

A partir de nuestras investigaciones (Díaz, 1998; 2000; 2004) hemos podido constatar que tanto los materiales constructivos como las técnicas arquitectónicas 
atribuibles a los periodos Ychsma e Inca en Armatambo, son claramente diferenciables y superpuestas entre sí. Así es observable la superposición de los adobes rectangulares sobre el tapial, lo que en correspondencia con otros elementos culturales asociados, nos ha permitido definir claramente la relación de cada una de estas técnicas con el periodo Ychsma o Inca respectivamente.

La arquitectura Ychsma utiliza el tapial de manera recurrente, el cual se empleaba en las grandes edificaciones, recintos ortogonales y pasajes de circulación interurbana. En la unidad de excavación "P", ubicada en la parte central de Armatambo (Díaz, 2004, vol I: 67-78), fue evidente la posición cronoestratigráfica del tapial, asociado a cerámica Ychsma, y subyacente al adobe rectangular de tipo Inca.

En esta unidad se descubrió un pasaje con rampa incorporada (Fig. 4) de más de $12 \mathrm{~m}$ de largo por 2,30 m de ancho, alineado en eje Norte-Sur. Esta pasaje está definido por dos gruesos muros de tapial de $1 \mathrm{~m}$ de ancho en promedio, por 3,60 $\mathrm{m}$ a 3,70 $\mathrm{m}$ de alto, cuyas bases fueron levantadas en zanjas poco profundas y directamente excavadas sobre los estratos naturales (Fig. 5). La construcción de estos tapiales se realizó mediante el acondicionamiento inicial de adobes achatados, de bordes descuadrados y con una sola superficie alisada, los que fueron dispuestos horizontalmente en doble hilera y unidos con argamasa de barro (Fig. 6a). Sobre estos se asentó una cama de barro de 20 cm de espesor, siguiendo la técnica de construcción de los tapiales. Luego de esa cama

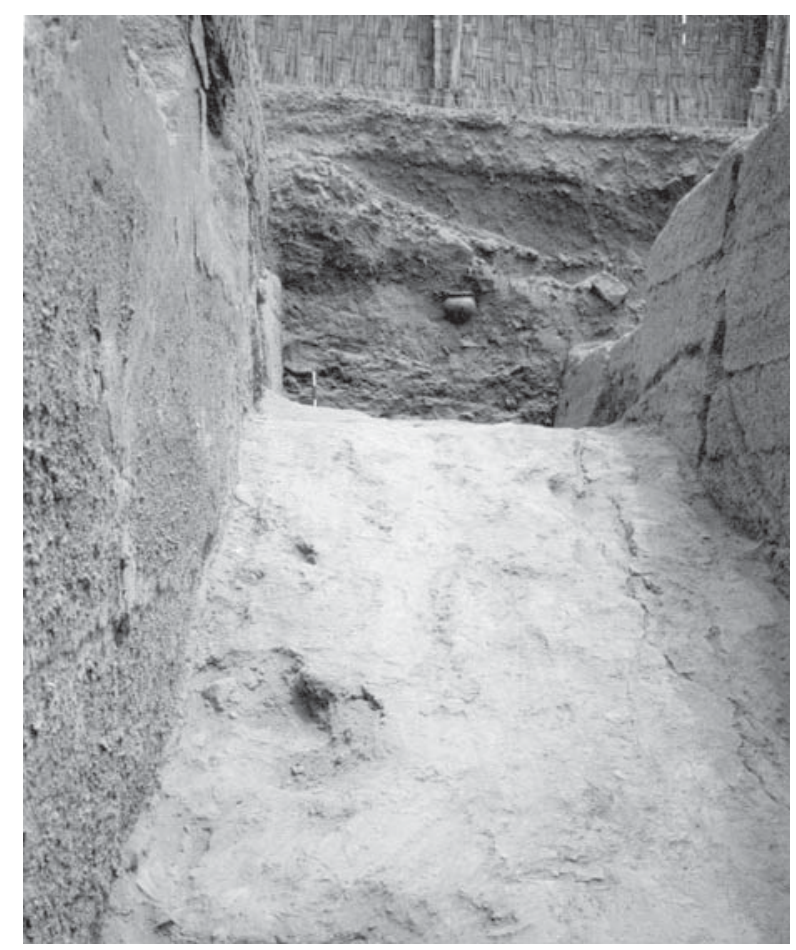

Fig. 4 - Pasaje con rampas. Unidad P. 


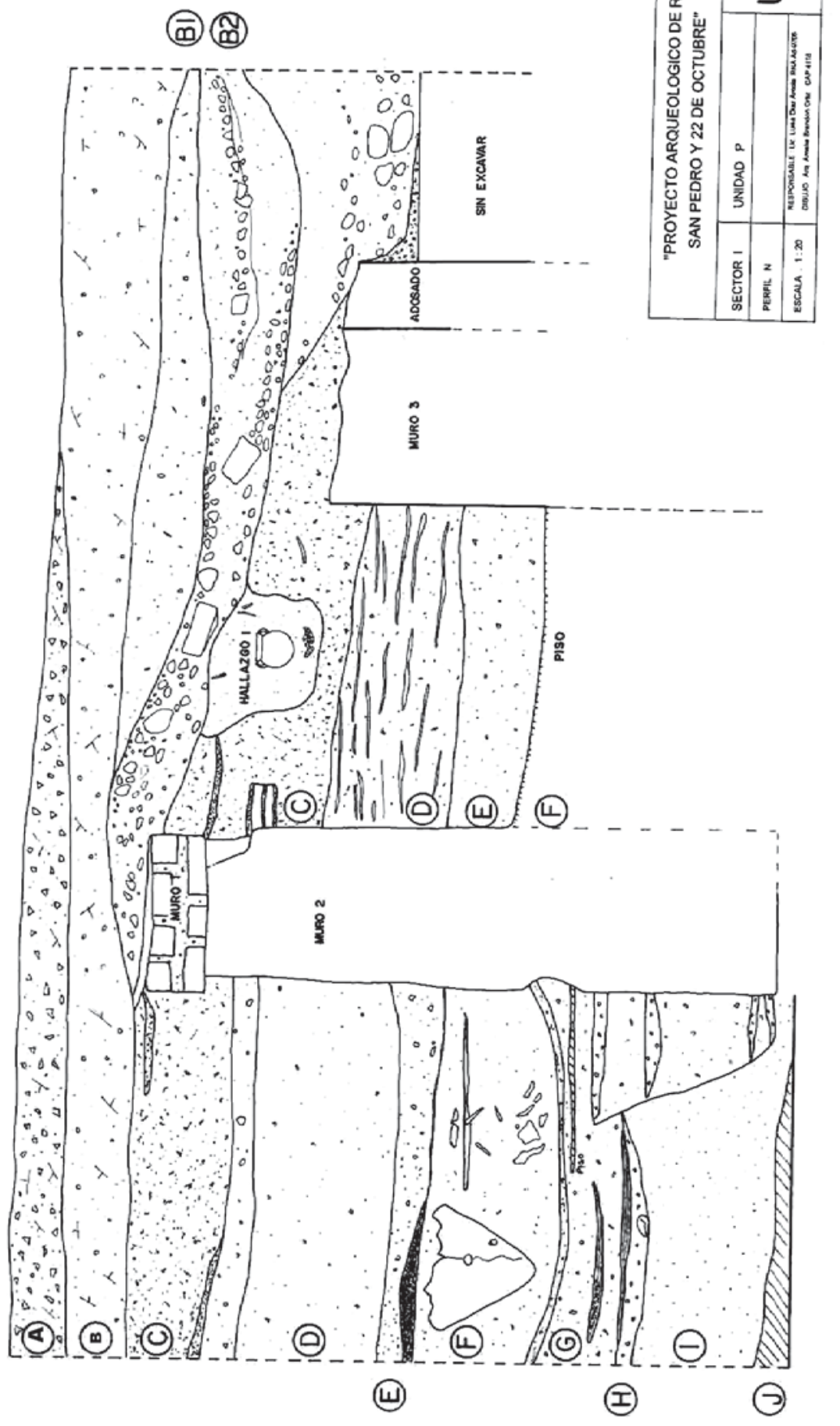

要 


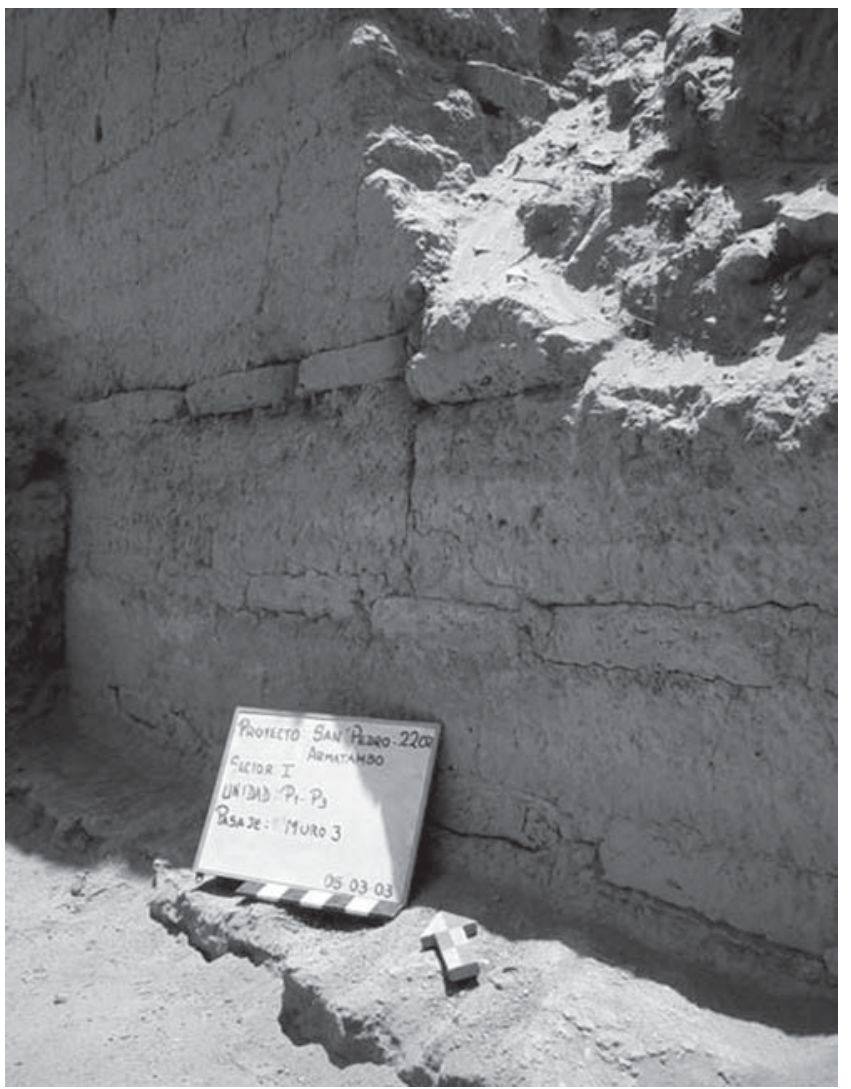

Fig. 6 - Detalle constructivo del tapial Ychsma. Unidad P.

de barro de $20 \mathrm{~cm}$ se puso nuevamente una línea de adobes achatados de las mismas medidas, los que otra vez fueron cubiertos por otra capa de barro de $32 \mathrm{~cm}$ de espesor, y al último se volvió a poner otra línea de adobes. Estos tapiales muestran en su superficie huellas de improntas de cañas, indicando que la caja que los contenía fue hecha con cañas dispuestas de manera vertical. Estos adobes tenían $40 \mathrm{~cm}$ de largo, $8 \mathrm{~cm}$ de alto y un espesor no precisado ya que se encontraban dentro del muro. Luego de esta primera porción del muro, que alcanza una altura de $90 \mathrm{~cm}$, se superponen más camas de barro que marcan notorias líneas horizontales, donde no se aprecian más adobes achatados.

El empleo de esta técnica constructiva también ha sido observado en algunas estructuras de la parte central de la Huaca San Pedro y en las unidades "O" y "X-3", ubicadas en otras zonas de la Huaca (Díaz, 2004, vol. I). En este punto es interesante notar la presencia de este tipo de adobes en el Templo Pintado (Muelle \& Wells, 1939: 274) en Pachacamac, indicándose que estos adobes fueron hechos con gaberas de madera, los que llevaban impresos huellas de dedos y que en promedio tenían 7 x 27 x 
$45 \mathrm{~cm}$. Además, esta técnica y este tipo de adobes están presentes en otros sectores de Armatambo, como por ejemplo en la Huaca Cruz de Armatambo (frontis y plataforma sur), Huaca Los Laureles (restos de muros en el lado oeste). En una revisión más detallada de los elementos arquitectónicos de Pachacamac, también se evidencia la presencia de este tipo de adobe, empleado no solo en asociación con los tapiales, sino conformando grandes edificaciones que emplean muros conformados exclusivamente con estos adobes achatados. Es interesante notar que, en general, las medidas de estos adobes suelen ser de $0,40 \mathrm{~cm}$ de largo x $0,10 \mathrm{~cm}$ de espesor $\mathrm{x} 0,26 \mathrm{~cm}$ de ancho, aunque también hay adobes de $0,42 \mathrm{~cm}$ de largo x $0,10 \mathrm{~cm}$ de espesor. La temporalidad de estos adobes y de estas técnicas constructivas se relaciona también con el periodo Medio y probablemente el periodo Temprano de desarrollo de la sociedad Ychsma; pues en el sector comprendido al este del montículo Urpayhuachac (Fig. 7), junto al cementerio III de Uhle (1903: plano general), se asocian estas estructuras con material cerámico de superficie perteneciente al Ychsma Temprano (Fig. 8) (1). En la Calle Este-Oeste de Pachacamac, próximo al cruce con la Calle Norte-Sur, se aprecia la superposición horizontal de un muro de adobes rectangulares grandes, que cubre un muro más antiguo confeccionado con adobes achatados.

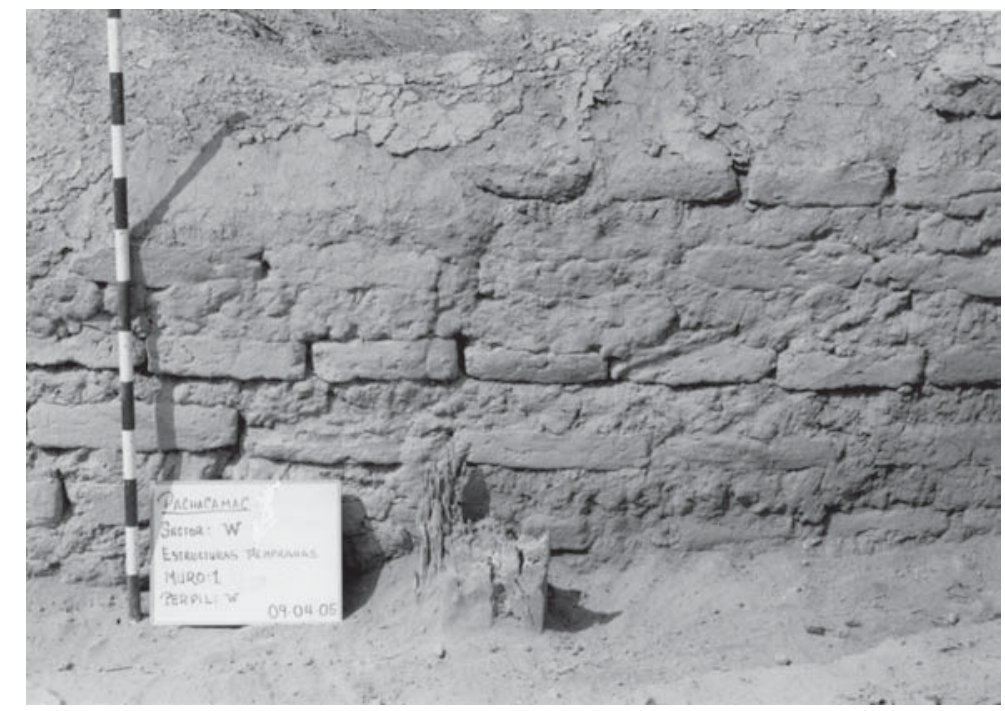

Fig. 7 - Foto de un muro con adobes achatados identificado en las estructuras al este del montículo Urpayhuachac.

(1) Esta cerámica guarda semejanzas con la cerámica que hemos podido revisar del sitio de Macattampu asignable al periodo Ychsma Temprano, existente en el MNAAHP, como también a la cerámica de inicios del periodo Medio, identificada en Armatambo (Díaz \& Vallejo, 2002). Las semejanzas se refieren a las formas y acabados identificados en la cerámica de este periodo. En cuanto a las formas, nos referimos a la presencia de cuellos altos, golletes de perfil compuesto, paredes gruesas, labios adelgazados, cuerpos globulares. En cuanto a los acabados, se aprecia la ausencia de decoración pictórica, restringiéndose al uso de un engobe blanco cremoso muy diluido. Los alisados son toscos y se emplean las líneas bruñidas aparentemente como forma decorativa. 

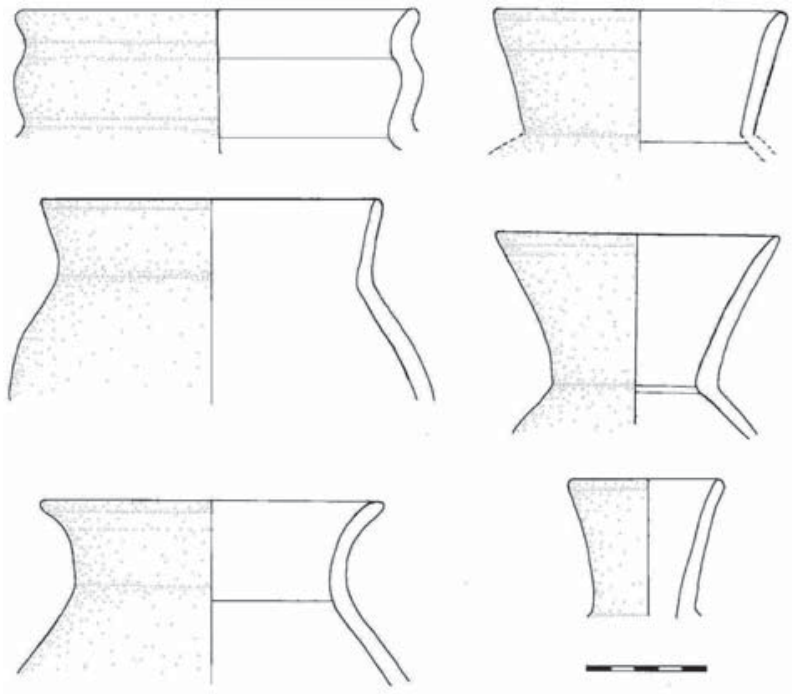

\section{Fig. 8 - Cerámica Ychsma Temprano identificada al este del montículo Urpayhuachac.}

En Armatambo, los recintos definidos por estos tapiales suelen ser de planta ortogonal, de tamaño pequeño ( $3 \mathrm{~m}$ en promedio) y tamaño mediano ( $5 \mathrm{~m}$ en promedio). En algunos casos también se han encontrado evidencias de pisos enlucidos en los recintos más elaborados. En términos generales la posición de los tapiales siempre es vertical y con escasa cimentación.

En cuanto a la arquitectura de la época Inca, la técnica constructiva cambia radicalmente, ya que se emplearán los adobes de manera frecuente en vez del tapial. Estos adobes son de forma rectangular "tipo Inca" (Tello, 1999a: 37) o paralelepípedos. Es resaltante notar que, en términos generales, los adobes rectangulares no son de un tamaño regular, pues lo que predomina son los adobes de tamaños variados, aunque la altura promedio puede fluctuar entre $\operatorname{los} 12 \mathrm{~cm}$ y $25 \mathrm{~cm}$. Las improntas en estos adobes son observadas por el lado superior, donde se pueden encontrar huellas de manos o de algún animal doméstico (como un perro), demostrando que esa es la superficie que estuvo totalmente expuesta dentro de la gavera. Los adobes Inca emplean algunas inclusiones en la mezcla arcillosa, como pequeñas piedras, fragmentos de moluscos o pedazos de cerámica en pequeñas proporciones. Las edificaciones construidas con estos adobes corresponden a PCR, como la de la Huaca San Pedro o recintos rectangulares como el Recinto con Pintura Mural de la unidad "O".

\section{1. La pirámide con rampa SP1 Ar.}

Como mencioné, el empleo de estos adobes ha sido encontrado en una de las PCR (Unidad “R”) recientemente excavada por nosotros en Armatambo (Díaz, 2004, vol. I; 
Díaz \& Vallejo, 2003a; 2003b) (Fig. 9) evidenciando la continuidad constructiva de los patrones arquitectónicas propios de la región Ychsma durante la ocupación Inca de este territorio, demostrando por ello una pervivencia muy significativa de las expresiones culturales locales. Asimismo, el empleo de este tipo de adobes ha sido encontrado en un pequeño recinto (Unidad “O”) con pintura mural Inca (Díaz, 2003: 45 -46).

La PCR de la Huaca San Pedro (SP1-Ar) corresponde a un edificio menor de $50 \mathrm{~m}$ por $25 \mathrm{~m}$, cuyo eje principal se orienta hacia el Este. Caracteriza a este espacio el aprovechamiento de la topografía inclinada del terreno, donde se erigió un edificio que fue ganando progresivamente altura mediante el uso de plataformas, de tal manera que se logró realzar su volumetría. En la plataforma más elevada se construyó el patio superior en $\mathrm{U}$, que presentaba recintos laterales y posteriores (Fig. 10), conectados con la plaza delantera a través de una rampa.

El patio en U muestra dos momentos constructivos atribuibles a la época Inca. El primero corresponde a una construcción que evidencia mayor cuidado en el tratamiento arquitectónico, como la presencia de finos enlucidos de $1 \mathrm{~cm}$ de grosor, sobre los que se realizaron algunos graffitis (Díaz, 2003: 48 y 49). Luego el segundo momento corresponde a un enterramiento, donde se construyeron muros sencillos y toscos que se superpusieron al primer momento constructivo (Fig. 11). Por las características del tratamiento arquitectónico que presenta este patio, y el poco desgaste observado, se puede concluir que estaba restringido a actividades de carácter ceremonial, mientras que en los recintos laterales se dieron actividades productivas y de descanso. Los rellenos de arena de los recintos superpuestos al patio en U, estaban en su mayoría limpios, pero al momento de sellarlos se realizaron algunos tipos de ofrendas, consistentes en concentración de vegetales y restos malacológicos, a modo de delgadas capas sobre los

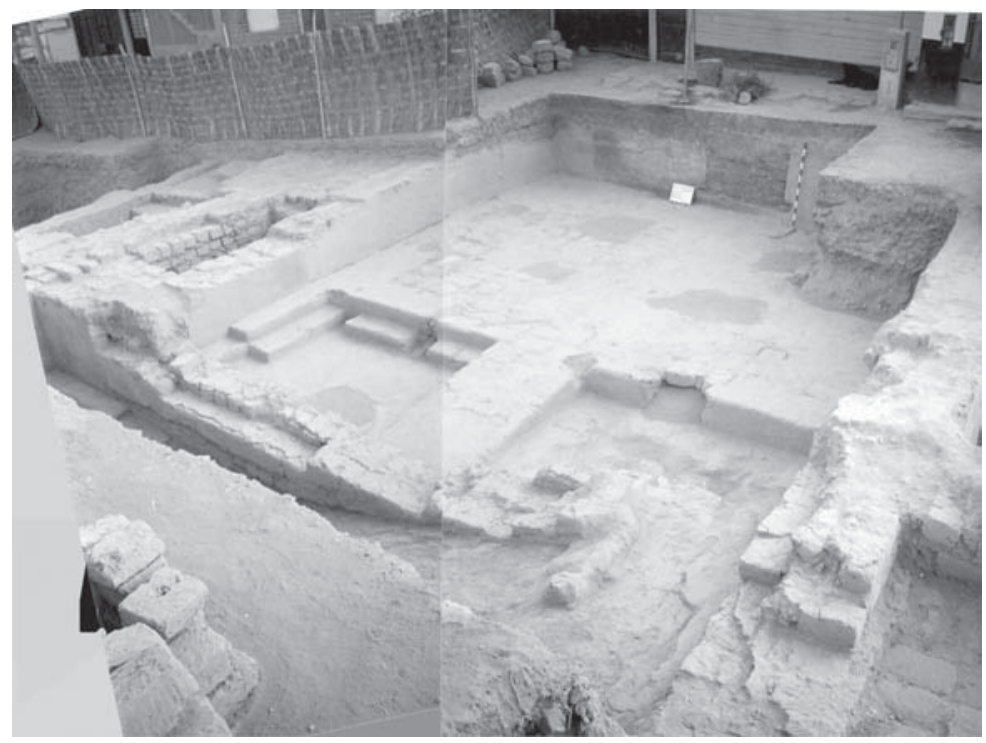

Fig. 9 - Patio en U. PCR SP1-Ar. Unidad R. 


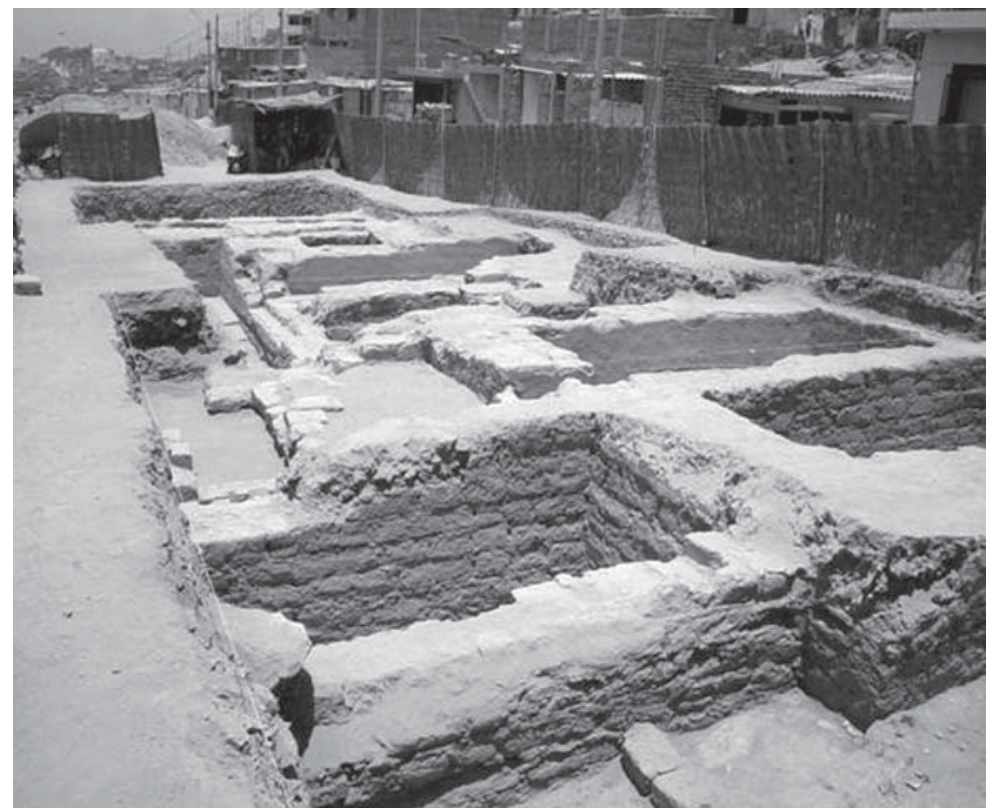

Fig. 10 - Recintos laterales del patio en U.

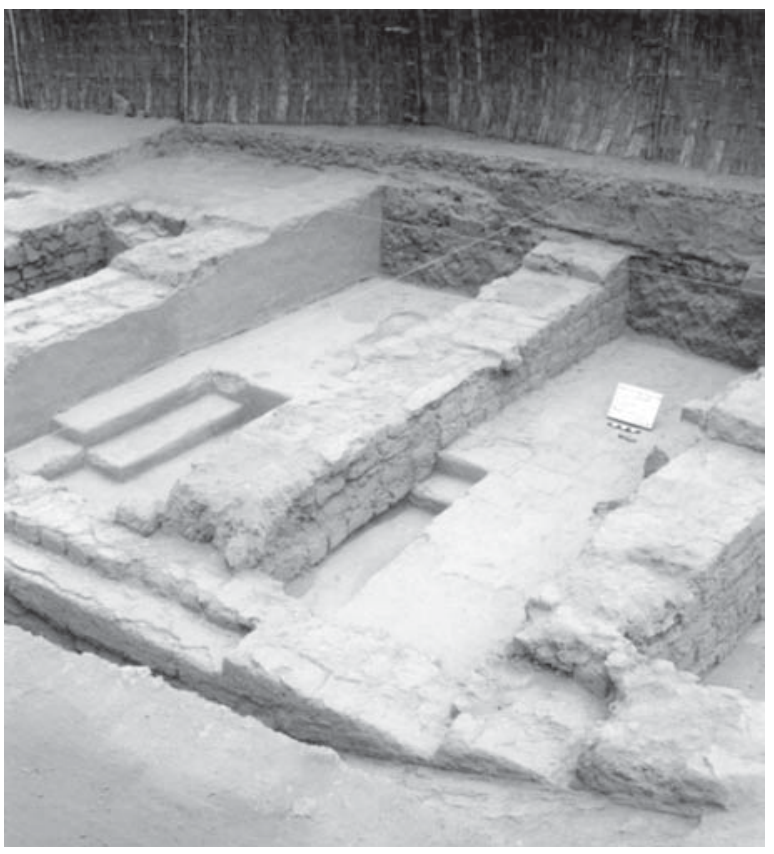

Fig. 11 - Obsérvese los muros superpuestos al patio en U, definiendo la técnica del emparrillado. 
pisos y esquinas. Dentro de los rellenos se han encontrado adobes enlucidos, infiriendo que los muros han sido derribados como parte del nuevo proceso constructivo.

Una rampa E-W es la que caracteriza a esta unidad arquitectónica. Se trata de una construcción de $2 \mathrm{~m}$ de largo por 1,20 m de ancho, con una elevación que va desde 0 a nivel del piso del patio, hasta $34 \mathrm{~cm}$ de altura, a nivel del piso elevado del patio. $\mathrm{Su}$ construcción se realizó utilizando adobes de $30 \mathrm{~cm}$ de ancho por $40 \mathrm{~cm}$ de largo en promedio, unidos con barro y recubiertos por un fino enlucido plomizo casi pulido hasta de $1,5 \mathrm{~cm}$ de espesor en la parte superior de la rampa.

En el piso elevado encontramos cuatro hoyos cubiertos de arena, ubicados en el centro del recinto. Podemos suponer que se trataban de los lugares donde descansaban los troncos o columnas. En el piso a nivel de la rampa encontramos otras dos intrusiones una a cada lado de la base de la rampa, en los que se encontraron restos de troncos que han sido removidos al momento de rellenar el patio. Las intrusiones se encontraban de manera equidistante guardando simetría entre sí con el patio, por lo que pensamos que todo el patio estaba techado al momento de su funcionamiento (2). En el extremo oeste del recinto se encontró un muro enlucido de $93 \mathrm{~cm}$ de ancho, con un vano que se ubica en el eje central de la rampa y los hoyos para los postes. El vano mide 1,40 m de ancho y se angosta ligeramente en la parte inferior; este se encontraba clausurado con tres filas de adobes que, al retirarlos, dejaron ver el relleno de arena del recinto al cual conduce. El vano no llegaba hasta el nivel del piso del patio, sino que se eleva a $20 \mathrm{~cm}$ por encima de él, formando un escalón con la impronta de un madero en el filo. El piso del vano es casi pulido muy similar al de la rampa pero con menor grado de desgaste, por ello asumimos que se trataba de un espacio aún más restringido, destinado solo a personalidades de rango elevado. Es necesario señalar, que los dos muros construidos para sellar el patio en U se construyeron alineados sobre los hoyos de poste, con lo que se cubrió cuidadosamente este espacio ceremonial, evitando el desplazamiento del relleno del patio, funcionando a modo de emparrillado.

\section{2. El recinto con pintura mural}

Este recinto (Recinto 2) fue construido reutilizando parte de un recinto ortogonal pre existente de mayores dimensiones (Recinto 1), el que fue construido anteriormente con muros de tapiales Ychsma. El Recinto 1construido durante el período Ychsma era de planta cuadrangular, con muros de tapial Ychsma, con la técnica de intercalar hileras de adobes achatados en la estructura del tapial. En el relleno de este recinto no se encontraron adobes o fragmentos de adobes del tipo Inca, lo que confirma la correspondencia cronológica del mismo y de su relleno posterior al Intermedio Tardío. El material cerámico presente es escaso, pero relacionado con fragmentos de grandes vasijas, como tinajas o cántaros grandes pertenecientes a la época Ychsma Medio,

(2) Franco (1998: 18, Fig.10) a partir de sus investigaciones en la PCR No 2 de Pachacamac realiza una reconstrucción del nivel superior del volumen aterrazado (sector III), en el que representa una hornacina central y columnas para sostener una techumbre. En nuestro caso, el patio en U presenta un vano central alineado en el eje de los postes. Estos dos casos evidencian una convención en el patrón arquitectónico Ychsma. 
algunos de ellos similares a los descritos anteriormente para esta época (Díaz \& Vallejo, 2002). La superficie de estos fragmentos corresponde a vasijas de superficie llana, de pasta muy oxidada. No se han identificado elementos decorativos adicionales. Funcionalmente, este recinto parece haber servido para actividades ceremoniales ligadas al depósito o utilización de grandes tinajas, de las cuales existían las improntas de su ubicación en el piso.

El Recinto 2 (Fig. 12), de planta rectangular (2,5 m x 1,5 m) y de características intrusivas con respecto a los muros y al relleno del Recinto 1, posee una escalinata indirecta de ingreso. La orientación básica de los muros es N-S y E-W, manteniendo iguales orientaciones que los muros del Recinto 1. Toda la estructura de la escalinata está hecha en adobes paralepipedos de tamaño mediano (34 x $24 \times 14)$, unidos por una argamasa de barro, aunque los muros que delimitan la escalinata son de una sola hilera de adobes, dispuestos en soga y apoyados directamente sobre el relleno del Recinto 1. Este hecho le confiere al muro que delimita la escalinata, como a ella misma, muy poca estabilidad estructural.

Tres de los muros de este recinto (norte, este y oeste) tenían evidencias de decoración mural (Fig. 13), siendo los muros norte y este los mejor conservados. Aunque se debe precisar que el trabajo de conservación más detallado se realizó en el muro este, por que la decoración pictórica se encontraba en mejor estado. Además,

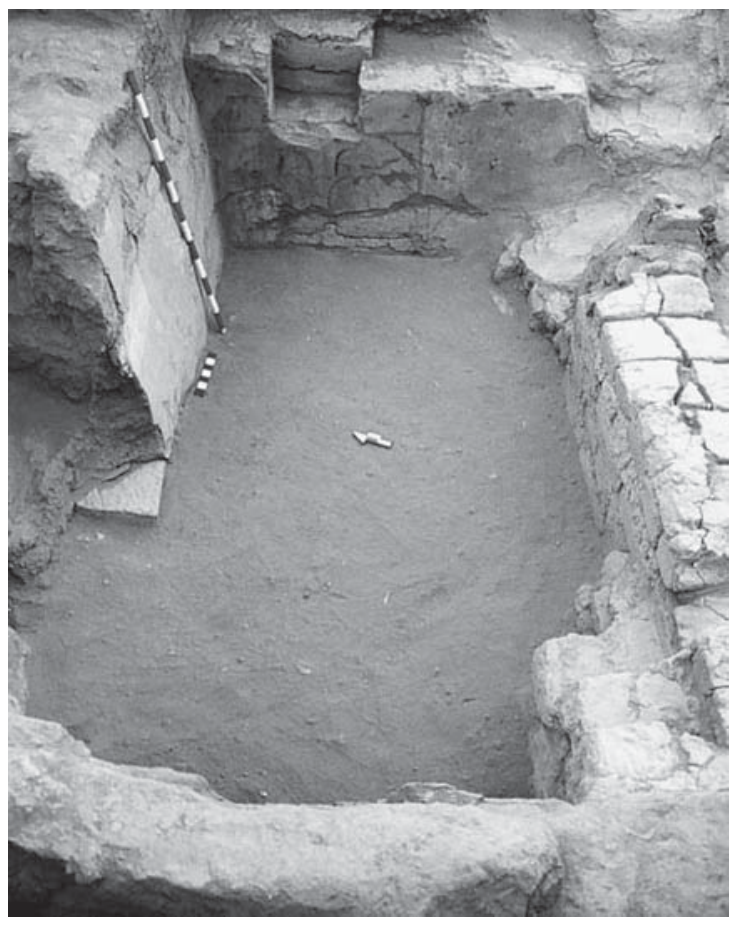

Fig. 12 - Recinto con pintura mural. Unidad $O$. 


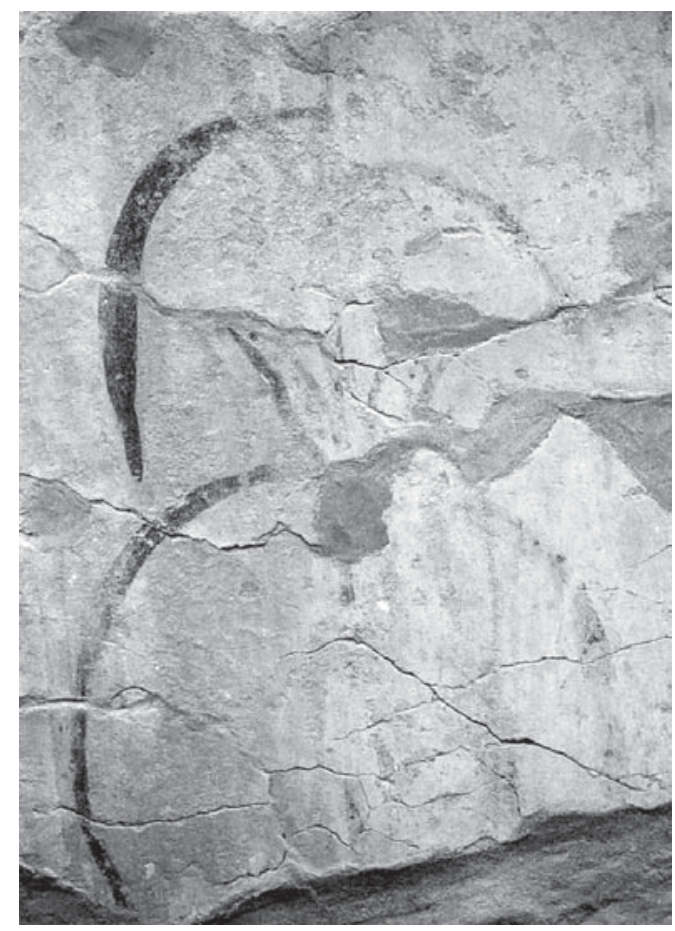

Fig. 13 - Detalle de decoración de maíz.

también se encontraron algunos pedazos de adobes con restos de pintura de peces (Díaz, 2003: 49) similares a los reportados por Uhle (1903) en Pachacamac (Muelle \& Wells, 1939), también investigados por Bonavia (1974) y Marcone (2003). El mural mejor conservado presentó un fondo amarillo ocre, sobre el cual se elaboraron dos diseños de plantas enteras de maíz (Díaz, 2003: 46), delineadas en negro y en rojo alternativamente. Estos maices se encontraban enmarcados dentro de dos paneles rectangulares delineados en rojo. Tanto el maíz dibujado en rojo como su panel respectivo, estaban a su vez remarcados en un color oscuro (¿negro ?) (3). Es apreciable distinguir en el tratamiento decorativo de estos murales una filiación estilística Ychsma, donde la convención es el tratamiento estilizado de ciertas representaciones también recurrentes en Pachacamac, como el maíz y los peces (Marcone, 2003). Finalmente, resulta contrastante la fina decoración de los muros, con la poca cimentación estructural de los mismos, aunque no cabe duda que esto constituye una evidencia excepcional. Todo el conjunto estructural del recinto pareciera haber utilizado tanto las técnicas como los materiales más a la mano, pues no se percibe un planeamiento elaborado del mismo y su construcción quizas obedezca a un momento coyuntural. El carácter intrusivo del recinto, su poca

(3) Estilísticamente el diseño de estas plantas de maíz se relaciona con algunas representaciones similares presentes en vasos de cerámica, también correspondientes a la época Inca hallados en Pachacamac (Eeckhout, 1995: Fig. 27) y Armatambo (Díaz, 2003: 46). 
elaboración arquitectónico-estructural, parece coincidir con un recinto de ofrenda o de uso momentáneo. Asimismo, en el sitio de Pachacamac también se registró este tipo de prácticas de recintos ceremoniales intrusivos a estructuras preexistentes. Tello (1999b) reporta el hallazgo de un recinto de la época Inca elaborado en piedra canteada de color rosado (4)que intruye una estructura más antigua y que en su concepción es muy similar al Recinto 2 de Armatambo (Fig. 14).

\section{EL PATRÓN FUNERARIO YCHSMA}

Los resultados de nuestras investigaciones respecto al patrón funerario Ychsma se respaldan en un número de 221 contextos funerarios excavados recientemente en las proximidades de la Huaca San Pedro. Hallamos 189 de ellos en el sector conocido como "22 de Octubre" (Díaz, 2004, vol. II) y que corresponde a un grupo funerario perteneciente a la sociedad Ychsma, mientras que los restantes fueron recuperados en la zona Huaca San Pedro (Díaz, 2004, vol. I). En este grupo la forma recurrente de preparación del individuo es el empleo del fardo, existiendo algunas variantes al interior

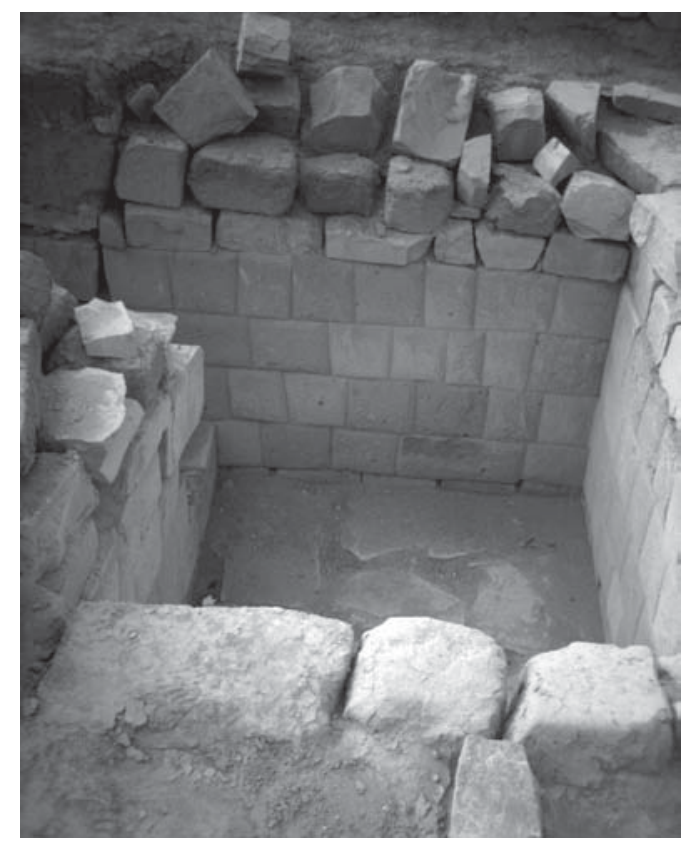

Fig. 14 - Recinto construido con piedra canteada de color rosado, identificado por Tello en Pachacamac entre 1940 y 1941.

(4) Este recinto mide 2,03 $\mathrm{m}$ de largo (N-S), 1,45 m de ancho (E-O) y $1 \mathrm{~m}$ de profundidad. Posee una escalera indirecta, donde el primer tramo presenta dos escalones, mientras que el segundo tiene tres escalones. El recinto preexistente es de planta cuadrangular construido con adobes rectangulares. 
de este tipo, dependiendo de los elementos que acompañan de manera estructural al envoltorio de telas. El ajuar funerario externo presenta varios rasgos comunes que, a pesar de las variantes, permiten definir la filiación cultural Ychsma, correspondiente a las fases Ychsma Medio e Ychsma Tardío A (5)(ver Vallejo en esta misma publicación), aunque existen algunas excepciones a la regla, como algunos entierros extendidos, los que por lo general carecen de ajuar funerario. Además sabemos muy poco a nivel antropológico sobre estos individuos, y sobre todo desconocemos la causa que motivó un tipo de enterramiento diferente. En términos generales, la investigación de este cementerio Ychsma nos ha permitido confirmar las características generales de este patrón observado en años anteriores, en el cementerio Ychsma de La Rinconada (Díaz, 2002) en el distrito de La Molina al este de la ciudad de Lima (6).

La elaboración del fardo, generalmente consiste en dos o tres telas simples (7) que envuelven al cuerpo. Mediante pliegues y simples costuras, se busca que las telas se acondicionen al cuerpo del individuo, que estará en posición flexionada si es adulto o sub-adulto. Al interior, el cuerpo presenta un tipo de relleno (8) que generalmente es de algodón en copos conservando sus semillas. El empleo de este último se tornará abundante y muy recurrente durante el Ychsma Tardío. Las variantes observadas radican en la presencia de otros elementos que se superponen a las telas que envuelven al cuerpo. Estos otros elementos pueden ser capas vegetales, presencia de cañas laterales, esterillas, mallas reticuladas de junco y con soguillas reticuladas. Este último caso, además, tiene una connotación cronológica, ya que el empleo de fardos revestidos con una malla hecha de soguillas reticuladas solo ha sido observado por nosotros, durante la fase Ychsma Tardío en Armatambo y en La Rinconada (Díaz, 2002), como también en la Huaca Granados (Mendoza, 1983: 9), en La Salina (Machacuay \& Aramburú, 1998: 48-49), por mencionar algunos.

Sin embargo, el patrón funerario Ychsma no solo presenta recurrencias en cuanto a la preparación del individuo, sino también en la disposición del ajuar funerario externo e interno y en la elaboración de la cista funeraria.

En cuanto a la preparación del cadáver, por lo general, los adultos presentan una posición flexionada de cubito dorsal, que es mantenida mediante la utilización de telas torcidas para sujetar al cuerpo en esa posición. Además se les practica un corte parcial

(5) La secuencia cronológica cerámica Ychsma propuesta por Vallejo (1998; 2004), que hemos venido utilizando (Díaz \& Vallejo, 2002; 2003c; 2004) señala tres épocas denominadas Ychsma Temprano, Medio y Tardío, donde al interior de cada una de ellas existen dos fases, denominadas respectivamente A y B, la que también es presentada en esta publicación.

(6) Recientemente hemos desarrollado una descripción más precisa del patrón funerario Ychsma de acuerdo con la secuencia cerámica Ychsma (Díaz \& Vallejo, en prensa)

(7) En términos generales ésta suele ser la norma en Armatambo y La Rinconada, pero también es posible encontrar fardos que llegan a poseer 4 a 5 capas de telas. Generalmente, las dos primeras telas suelen ser llanas, 2 × 2, balanceadas, mientras que las telas interiores pueden presentar decoración de listas, que combinan gamas del color marrón, o del color marrón y el color azul. El material utilizado suele ser el algodón.

(8) En el sitio arqueológico La Rinconada Alta, de los 104 individuos recuperados en el año 2002, en 5 individuos aproximadamente se utilizó una fibra vegetal no identificada, tipo grama ( $i$ ?), dispuesta a modo de atados, conformando el relleno del fardo. El ajuar funerario externo es pobre o nulo. 
del cabello, dejándolo muy corto, incluso en las mujeres. El individuo suele tener una posición central en la cista circular, que es excavada directamente en el suelo, sin presencia de ningún acondicionamiento estructural. Este hoyo puede realizarse intruyendo capas naturales, capas de basura e incluso removiendo parcialmente entierros anteriores. Los entierros suelen ser individuales, con el ajuar funerario externo ubicado en forma de media luna frente al individuo, que puede estar dispuesto en uno o dos niveles.

La presencia de metales está restringida a algunas láminas pequeñas en las órbitas de los ojos, en la boca o fragmentos de éstas en una de las manos. Los metales suelen ser de una mala aleación. Los varones suelen presentar pinzas en las manos, mientras que algunas mujeres pueden presentar algunas láminas de forma irregular que son dobladas y puestas en las palmas cerradas de las manos. Otra recurrencia es la presencia de una suerte de hilos enmadejados que envuelven las manos tanto de los individuos masculinos como femeninos. Al interior del fardo, y dispuestos en pequeños grupos a cada lado del individuo, se pueden encontrar grupos de dos o de cuatro cañitas huecas, que poseen tapones de algodón, al parecer utilizados para impedir que algún contenido se pierda. Un rasgo muy particular del patrón funerario Ychsma, y que se da mayormente en su época Media y Tardía, es la utilización de un gran mate circular relleno de ceniza que se encuentra siempre dispuesto al interior del fardo como asiento del cadáver.

En cuanto a los individuos que se entierran en posición extendida podemos señalar a los infantes, los que son preparados en pequeños fardos, sujetos mediante soguillas a una camilla hecha de carrizos cortos. Es la camilla la que da el soporte estructural al fardo, el que luego de preparado es dispuesto en un hoyo simple en posición vertical. Se observa que algunos niños pueden presentar pequeñas laminas de metal al interior del fardo, así como algunas vasijas formando parte del ajuar externo.

Un contexto funerario sumamente atípico, lo constituyó el entierro simbólico de unos báculos (Fig. 15), ubicado cronológicamente en el período Ychsma Medio de acuerdo a la cerámica asociada. Este consistió en una cámara rectangular en un eje EsteOeste $(2 \mathrm{~m} \times 0,95 \mathrm{~m})$ construida con adobes rectangulares — bastante más alargados que anchos- que contenía los dos báculos de madera, uno llano y más pequeño, y el otro tallado y de mayor tamaño. En ambos casos las bases de los báculos estaban desgastadas y aplanadas, como si permanentemente hubiesen sido golpeados sobre una superficie plana. Sobre las puntas lanceoladas de estos 2 instrumentos se depositaron 6 vasijas. En este grupo de vasijas destacó una, modelada con la figura de un prisionero atado de pies y manos (Fig. 16). El tratamiento superficial alisado simple y la aplicación del engobe blanco "cremoso chorreado" sobre algunas porciones de la vasija es un rasgo típico del Ychsma Medio.

En la parte externa de la cámara y en posición paralela a esta se encontró un individuo extendido que presentó los tobillos y los muslos sujetos por una fibra vegetal trenzada. La asociación de la cámara y de este individuo es clara ya que forman parte de la misma matriz. Desconocemos el acto ritual preciso que esté representando, pero no hay duda de que se trata de una de las pocas manifestaciones de autoridad y poder reconocidas para la sociedad Ychsma. Otro contexto funerario Ychsma, único y que también denota jerarquía es el C.F. 162 (Díaz, 2004, vol II), recuperado en el sector de "22 de Octubre". Este contex to consiste en una cista de planta ovalada de $2 \mathrm{~m}(\mathrm{E}-\mathrm{W}) \mathrm{x}$ 


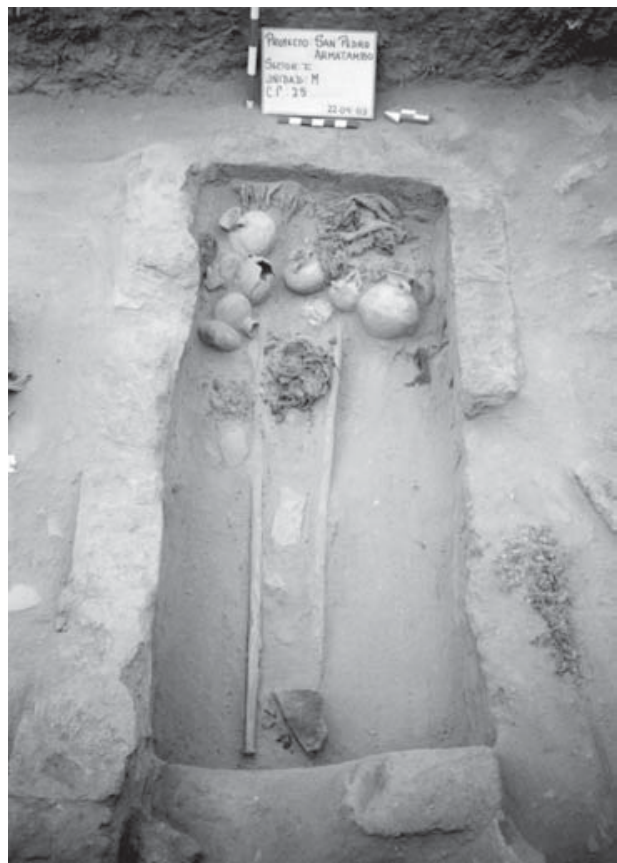

Fig. 15 - Entierro simbólico de dos báculos, identificados en el sector de San Pedro.

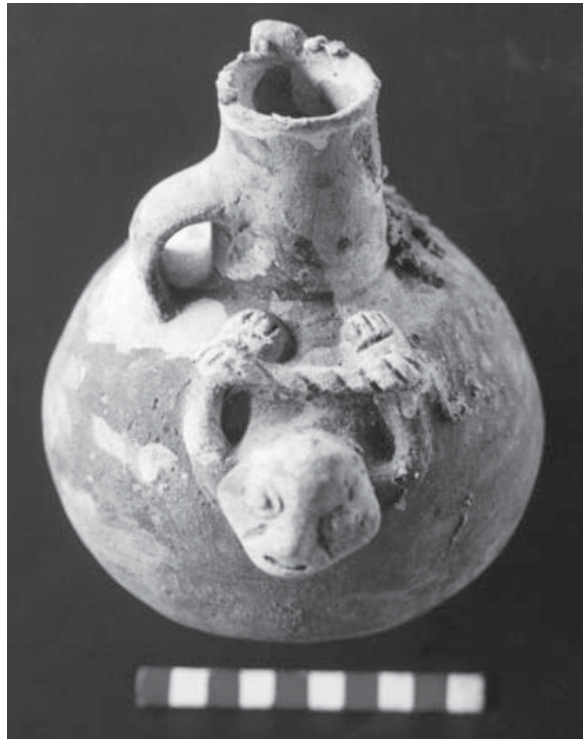

Fig. 16 - Vasija escultórica representando a un prisionero. Esta vasija formó parte del ajuar funerario asociado al entierro de los báculos. Estilísticamente esta vasija pertenece al Ychsma Medio. 
2,80 m (N-S), dentro de la cual se inscribe una cámara rectangular de paredes laterales de cañas, con techumbre tipo barbacoa. Esta cámara contenía dos individuos principales, un adulto y un niño, los que estaban enfardelados mirando hacia el Sureste. El ajuar funerario presentaba, entre otras cosas, collares de nectandras, collares de chaquiras, un textil con plumas negras, un penacho de plumas, 10 vasijas de cerámica, dentro de las cuales habían por lo menos 3 vasijas escultóricas. Sin embargo, lo más interesante es que, asociados a ellos, se encontraron alrededor de 12 individuos: un adulto, dos niños y nueve neonatos. La presencia de los recién nacidos llama mucho la atención ya que estamos ante una práctica funeraria observada en algunos otros contextos funerarios, pero en mucho menor cuantía, sustentada en creencias para nosotros desconocidas.

Finalmente, hay que señalar que existe una preferencia recurrente en cuanto a la ubicación de los cementerios Ychsma, ya que estos son ubicados en pequeñas hondonadas, con suelos calichosos y cubiertos de arena, los que se utilizan por estar alejados de los centros con arquitectura monumental, a diferencia de lo que sucede en la época Inca donde la tendencia es a enterrarse intruyendo espacios arquitectónicos o cerca de ellos.

\section{LOS OBJETOS SUNTUARIOS}

En Armatambo uno de los elementos suntuarios más representativo y de valor cronológico es el mullu (Spondylus princeps), ya que nos permite establecer la presencia del Estado incaico en la región Ychsma, debido a que su presencia es diferencial durante los periodos Intermedio Tardío e Inca. El mullu suele ser abundante en los contextos funerarios y de otros tipos durante el periodo Inca, mientras que su presencia es mínima o inexistente en los ajuares funerarios Ychsma. Creemos que esto responde a una fuerte limitación en cuanto a la disponibilidad del mullu para las diferentes prácticas sociales de la población local, quedando su acceso restringido únicamente a las clases gobernantes. La poca presencia del mullu durante el Intermedio Tardío en Armatambo, y en la región Ychsma en general, evidenciaría escasos niveles de intercambio con la costa norte. Luego de que la Costa Central fuera conquistada por el Estado Inca se dinamizó la circulación de este bien, permitiendo el ingresó de grandes volúmenes de este bivalvo a la región de Lima, logrando que la población tenga mayor acceso a este.

Los escasos niveles de intercambio percibidos en Armatambo durante el Intermedio Tardío, no solo se expresa en la popularidad del mullu, sino que también se observa con los metales, con los pigmentos y con otros moluscos (Conus sp y Ostrea sp) propios de las aguas cálidas. Esto estaría manifestando bajos niveles de intercambio con grupos sociales extrarregionales, lo que reforzaría la percepción de que el culto muy extendido de Pachacamac haya sido una creación incaica y no de origen local.

La gran presencia de mullu, conus y ostras en los registros arqueológicos de Armatambo se da durante la ocupación Inca y, al parecer, debe estar respondiendo a la eficaz red de comercio y/o tributación desplegada por la administración imperial Inca luego de anexar los pueblos de la región norte del Perú y del Ecuador, logrando con esta red, que productos suntuarios diversos llegaran de manera permanente a distintas partes del imperio como Pachacamac. En esta red de manejo administrativo y circulación de bienes creemos que Armatambo jugó un rol geopolítico importante, ya que era el puerto 
más cercano al Santuario que podía ser utilizado por embarcaciones de mayor tamaño. Además, debemos tener en cuenta que Armatambo se vinculaba a Pachacamac por medio del "Camino de los Llanos", el que atravesaba la ciudad de norte a sur. Estas condiciones geográficas particulares, al parecer, le dieron a Armatambo un mayor status económico y social durante la época incaica, constituyéndose en un foco de crecimiento para una clase social de mercaderes locales que alcanzaron una elevada posición económica, dentro del nuevo tejido social incaico.

\section{CONCLUSIONES}

De acuerdo con nuestras investigaciones en Armatambo, y complementadas con los trabajos también realizados en La Rinconada, podemos afirmar que los Ychsma durante el Intermedio Tardío se configuran como una formación social restringida a las cuencas bajas de los ríos L urín y Rímac, además de ocupar la zona de Chilca, área de litoral. Durante esta época, la ubicación de Armatambo debe haber respondido a su proximidad a la bahía, hoy conocida como de Chorrillos, cuyas aguas tranquilas fueron punto de acceso a los recursos alimenticios (caza de mamíferos marinos, pesca, etc.) que proveía el mar. De otro lado, la diversidad de recursos de playa arenosa, playa rocosa y humedales de la zona favorecieron grandemente su ubicación, sin olvidar los campos agrícolas que se extendían en sus faldas, alimentados por el canal de Surco o "Sulco". En la concepción de su ubicación se escogió y aprovechó la falda del Morro Solar que permitía tener una relación visual con la ciudad de Pachacamac, sumado al hecho de encontrarse resguardada de los vientos y neblinas provenientes del mar.

La arquitectura local, manifiesta en la utilización de tapiales con adobes achatados en su interior, definía varios espacios ortogonales abiertos, algunos poseyendo banquetas, los que se articularían entre sí mediante el uso de pasadizos con rampas. No es posible para nosotros tener aún una idea clara de la configuración urbana de Armatambo en esa época, pero es probable que el sector de PCR observado en las fotos aéreas (SAN 1943) se haya comenzado a construir en este periodo, tal vez concentrando la arquitectura monumental hacia la porción norte de la ciudad.

En cuanto a las costumbres funerarias pre incas, estas evidencian simplicidad en el tratamiento de los individuos y escasa presencia de productos extrarregionales (metales, moluscos exóticos del norte). Por ello, no se aprecia mayor diferenciación de status o diferenciación social en las actividades realizadas a través de los ajuares externos asociados. Sin embargo, son apreciables los pocos casos que evidencian jerarquía y poder como es el caso particular del contexto de los báculos y el contexto funerario complejo identificado en "22 de Octubre".

La escasa presencia de productos suntuarios obtenidos mediante la actividad del comercio a larga distancia, nos configurarían una sociedad circunscrita a resolver su existencia principalmente con los recursos obtenidos en su espacio territorial, aunque eventualmente accedía a algunos productos suntuarios exóticos, los que eran empleados en las prácticas rituales. Obviamente, este panorama se podrá ampliar luego de analizados otros elementos asociados que por ahora no contamos. En todo caso, todo pareciera indicar que los Ychsma estarían resolviendo mayoritariamente su distintas necesidades mediante la obtención de recursos de los valles o regiones más próximos. 
Sin embargo, la situación en la región Ychsma cambiará radicalmente durante la ocupación Inca. Los cambios son muy perceptibles en la arquitectura, ya que se introducirá la utilización de los adobes rectangulares del tipo Inca. Creemos que esta nueva adopción responde a la forma y necesidades urbanísticas de la administración incaica, creando la posibilidad de construir estructuras variadas, con muros más delgados y menos masivos. Es claro que la utilización de tapiales no podría facilitar la edificación de espacios reducidos y diversificados con poco esfuerzo y menor traslado de materia prima.

Es así que se continuará construyendo las PCR (SP1- Ar) propias de la región Ychsma, empleando esta innovación arquitectónica incaica. En cuanto a la distribución urbanística de Armatambo, es claro que se definen sectores o barrios, articulados entre sí por medio de un camino principal que cruza la ciudad de Norte a Sur, del cual se desprendían los caminos secundarios, algunos de ellos construidos durante el periodo Ychsma (Unidad P) y posteriormente reutilizados por los incas. Asimismo, hacia el sur de la ciudad se habrían ido construyendo de manera aislada y separadas algunas PCR menores como la excavada por nosotros en la zona de San Pedro.

En cuanto a las prácticas funerarias, es evidente que las convenciones de su patrón, el hoyo de planta circular excavado en el suelo, el tratamiento del individuo enfardelado, la posición central del mismo dentro de la cista y la disposición del ajuar funerario frente al individuo, se mantienen y no cambian. Lo que cambia es la riqueza de los ajuares funerarios, acrecentados por la presencia masiva de productos exóticos, sobre todo provenientes de la costa norte. Cambia además la complejidad del tratamiento externo del fardo y la mayor presencia de vasijas decoradas y modeladas, como el tipo "cara-gollete" identificado en Puerto Viejo (Bonavía, 1959). Contemporáneamente, se observará la presencia de contextos funerarios de planta rectangular, como el C.F. 24 (Díaz \& Vallejo, 2003b: 370) con adobes reutilizados, atribuibles a la elite local vinculada a la administración incaica.

De acuerdo a las evidencias arqueológicas presentadas, se puede afirmar que el periodo Inca en Armatambo y La Rinconada demuestra una incorporación vertical paulatina de nuevos elementos culturales y no de una suplantación de los mismos. Esta es la manera que permite explicar la continuidad de la tradición cultural Ychsma, que subsiste a pesar de su anexión al estado imperial incaico.

\section{Referencias citadas}

BANDELIER, A., 1970 - De Adolph Bandelier a Thomas Janvier (Carta). In: 100 años de Arqueología en el Perú; Lima: IEP y Petroperú.

BONAVIA, D., 1959 - Cerámica de Puerto Viejo (Chilca). In: Actas del II Congreso Nacional de Historia del Perú 1958, vol. 2: 137-178; Lima.

BONAVIA, D., 1974 - Ricchata Quellcani: pinturas murales prehispánicas, XV, 187p.; Lima: Banco Industrial del Perú, Fondo del Libro.

BUENO, A., 1978 - Chorrillos Arqueológico. Revista Espacio, No 3; Lima. 
CERDAN y PONTERO, A., 1901[1793] - Tratado General sobre las Aguas que Fertilizan los Valles de Lima. In: Leyes, Decretos, Resoluciones, Reglamentos y Circulares vigentes en el Ramo de Justicia, Tomo I, Legislación de Aguas: 327-515; Lima: Edición Oficial.

COBO, Fray B., 1882[1639] - Historia de la Fundación de Lima, tomo 1, 334p.; Lima: Imprenta Liberal. Publicación y notas de M. González de la Rosa.

DIAZ, L., 1998 - Informe Técnico del Proyecto Arqueológico en la Modalidad de Rescate "Héroes del Pacifico" II Etapa. Manuscrito en el archivo del Instituto Nacional del INC; Lima.

DIAZ, L., 2000 - Informe del Proyecto Arqueológico de Rescate "A.H. San Pedro" - Armatambo, Chorrillos. Manuscrito en archivo del Instituto Nacional de Cultura; Lima.

DIAZ, L., 2002 - Informe del Proyecto de Rescate Arqueológico Rinconada Alta, IV Etapa. Manuscrito en archivo del Instituto Nacional de Cultura; Lima.

DIAZ, L., 2003 - Murales, bajorrelieves y grafittis en la Arquitectura Ichma-Inca. Medio de Construcción, No 178: 44-49; Lima.

DIAZ, L., 2004 - Informe Final del Proyecto Arqueológico de Rescate "A.H. 22 de OctubreArmatambo", Chorrillos. Volúmenes I, II y III. Manuscrito en archivos del Instituto Nacional de Cultura; Lima.

DIAZ, L. \& VALLEJO, F., 2002 - Identificación de Contextos Ichma en Armatambo. Revista Arqueología y Sociedad, No 14: 47-75; Lima: Museo de Arqueología y Antropología de la UNMSM.

DIAZ, L. \& VALLEJO, F., 2003a - Hallazgo de Pirámides con Rampa en Armatambo. Medio de Construcción, $\mathbf{N}^{\mathbf{0}}$ 175: 49-54; Lima.

DIAZ, L. \& VALLEJO, F., 2003b-Armatambo y el dominio incaico en el valle de Lima.-Boletín de Arqueología PUCP-2002, $\mathbf{N}^{\circ}$ 6: 355-374; Lima.

DIAZ, L. \& VALLEJO, F., 2003c - Variaciones en los Patrones Culturales Locales de Lima durante la Ocupación Inca. Ponencia presentada en el $51^{\circ}$ Congreso Internacional de Americanistas; Santiago de Chile. Julio de 2003.

DIAZ, L. \& VALLEJO, F., 2004 - Variaciones culturales en el valle de Lima durante la ocupación incaica. Chungara, Revista de Antropologia Chilena, Vol. 36 N$^{\circ}$ 2: 295-302; Arica: Universidad de Tarapacá. Julio- Diciembre 2004.

DIAZ, L. \& VALLEJO, F., en prensa - Los Contextos Funerarios Ychsma: Armatambo y La Rinconada Alta. Ponencia presentada en el "III Seminario de Arqueología UNFV, Muerte y Evidencias Funerarias en los Andes Centrales: Avances y Perspectivas", Setiembre de 2004; Lima.

EECKHOUT, P., 1995 - Pirámide con Rampa No 3 de Pachacamac, costa central del Perú. Resultados preliminares de la primera temporada de excavaciones (zonas 1 y 2). Bulletin de l'Institut Français d'Études Andines, 24(1): 65-106; Lima.

FERNÁNDEZ CONCHA, J., 1958 - Geología del Morro Solar-Lima. Boletín de la Sociedad Geológica del Perú, Tomo 33: 1-50; Lima.

FRANCO, R., 1998 - La Pirámide con Rampa $N^{\circ} 2$ de Pachacamac. Excavaciones y nuevas interpretaciones, 105p; Trujillo.

HYSLOP, J. \& MUJICA, E., 1992 - Investigaciones de A.F. Bandelier en Armatambo (Surco).Gaceta Arqueológica Andina, Vol. VI No 22: 63-86; Lima: INDEA.

MACHACUAY, M. \& ARAMBURÚ, R., 1998 - Contextos Funerarios Tardíos en La Salina, Valle del Rimac. Arqueología y Sociedad, No 12: 37-50; Lima: MNAA de la UNMSM.

MARCONE, G., 2003 - Los Murales del Templo Pintado o Relación entre el Santuario de Pachacamac y la Iconografía Tardía de la Costa Central Peruana. Anales del Museo de América, 11: 57-80; Madrid.

MENDOZA, M., 1983 - Huaca Granados, Valle del Rimac. Gaceta Arqueológica Andina, N 7 : 8-10; Lima: INDEA.

MUELLE, J. \& WELLS, R., 1939 - Las Pinturas del Templo de Pachacamac. Revista del Museo Nacional, Tomo VIII No 2: 265-282; Lima. 
ROSTWOROWSKI, M., 1977 - Etnía y Sociedad. Costa Peruana Prehispánica, 293p.; Lima: IEP.

ROSTWOROWSKI, M., 1978 - Señoríos Indígenas de Lima y Canta, 280p.; Lima: IEP.

TELLO, J. C., 1999a - Arqueología del Valle de Lima; Lima: Museo de Arqueología y Antropología de la Universidad Nacional Mayor de San Marcos. Cuadernos de Investigación del Archivo Tello $\mathrm{N}^{\circ} 1$.

TELLO, J. C., 1999b - Memoria Sucinta sobre los Trabajos Realizados en las Ruinas de Pachacamac durante los años 1940 y 1941. Revista del Museo de Sitio Pachacamac Urpiwachac, $\mathbf{N}^{\circ} \mathbf{1}$, Julio-Agosto 1999.

VALLEJO, F., 1998 - Secuencia cronológica en base a la cerámica Ichma. Documento presentado en el Primer Coloquio de Arqueología del Valle del Rímac durante el Período Intermedio Tardío; Lima: INC-Museo de Puruchuco.

VALLEJO, F., 2004 - El Estilo Ychsma: Características generales, secuencia y distribución geográfica; Lima. Ms.

VARÓN GABAI, R., 1997 - Surco, Surquillo y Miraflores. La gente y sus recursos entre los siglos XVI y XX. In: Arqueología, Antropología e Historia en los Andes. Homenaje a María Rostworowski (Rafael Varón Gabai \& Javier Flores Espinoza, eds.): 443-470; Lima: IEP- BCP.

UHLE, M., 1903 - Pachacamac; Philadelphia: Department of Archaeology, University of Pennsylvania. 